\title{
Aluminum Affects the Antioxidant Activity of Tobacco Cells and the Expression of Salicylate-Induced Protein Kinase (SIPK)
}

\author{
Atefeh PAYEZ ${ }^{1}$, Faezeh GHANATI ${ }^{1 *}$, Seyed Mahdi SEYEDI ${ }^{2}$ \\ ${ }^{1}$ Tarbiat Modares University, Department of Plant Biology, Faculty of Biological Science, \\ Tehran,Iran;ghangia@modares.ac.ir ("corresponding author) \\ ${ }^{2}$ National Institute for Genetic Engineering and Biotechnology Tehran, Iran
}

\begin{abstract}
It has been shown that Aluminum $(\mathrm{Al})$ toxicity results in over-production of reactive oxygen species (ROS). Despite the fact that ROS can induce MAPK activation, no direct genetic evidence has linked ROS-induced MAPK activation with Al toxicity. The effect of $\mathrm{Al}$ on the activation of antioxidant systems in connection with the expression of salicylate-induced protein kinase (SIPK), was examined in tobacco cells. Suspension-cultured tobacco cells (Nicotiana tabacum L. cv. 'Barley 21') were treated with or without $80 \mu \mathrm{M}$ Al. Certain parameters related to antioxidant activity were measured. A MAPKK inhibitor (PD98059) was also applied together with or without $\mathrm{Al}$ treatments and semi quantitative RT-PCR was applied to show the expression level of the SIPK gene. Treatment with Al rapidly increased the radical scavenging capacity of cells, catalase and superoxide dismutase activities, and expression of the SIPK gene, as compared to the control cells. In the presence of $\mathrm{Al}+\mathrm{PD} 98059$, a decrease in catalase and superoxide dismutase activities was observed, compared to those cells which were treated only with $\mathrm{Al}$. These results suggested that a short treatment with $\mathrm{Al}$ induced the activity of certain antioxidant enzymes in tobacco cells and that this response was mediated by a MAPK signal transduction pathway.
\end{abstract}

Keywords: aluminum, antioxidant system, MAPK cascade, Reactive Oxygen Species (ROS), Salicylate-Induced Protein Kinase (SIPK), tobacco cells

\section{Introduction}

Aluminum (Al) toxicity is the most widespread form of metal toxicity experienced by plants grown in acidic soils (Zhang et al., 2010). The steps that initiate the signaling response of plants to $\mathrm{Al}$ are not known. Although it is assumed that $\mathrm{Al}$ exerts its toxic effect in the apoplast through interaction with the negative binding sites of the cell walls (Schmohl and Horst, 2000), at the cellular level plasma membrane is considered as the primary target of Al. Strong affinity of $\mathrm{Al}$ for bio-membranes and its interference with membrane lipids or membrane proteins can increase the membranes rigidity, which seems to facilitate the radical chain reactions mediated by $\mathrm{Fe}$ ions enhancing the production of reactive oxygen species (ROS), and peroxidation of membrane lipids (Cakmak and Horst, 1991; Yamamoto et al., 2003).

It has been shown that $\mathrm{Al}$ can act upon the signal transduction pathway specifically reducing the activity of phospholipase C (PLC), consequently followed by inhibition of IP3, regulation of calcium release and activation of protein kinases, e.g., MAPK (Jones et al., 1995). It is now clear that heavy metals activate MAPKs in several plant systems. For example exposure of alfalfa (Medicago sativa) seedlings to excess $\mathrm{Cu}$ or $\mathrm{Cd}$ ions activated four distinct mitogenactivated protein kinases (Jonak et al., 2004). Despite the fact that ROS can induce MAPK activation, no direct genetic evidence has linked ROS-induced MAPK activation with $\mathrm{Al}$ toxicity. MAPK cascades minimally consist of a MAPKKK-MAPKK-MAPK module that is linked in various ways to upstream receptors and downstream targets. In tobacco the major ROS-induced MAPK is salicylateinduced protein kinase (SIPK) (Samuel and Ellis, 2002). In the present study rapid effects of $\mathrm{Al}$ on lipid peroxidation (LPO), radical scavenging capacity and activation of superoxide dismutase (SOD) and catalase (CAT), as well as the expression of SIPK in suspension-cultured tobacco cells, were investigated.

\section{Materials and methods}

Suspension-cultured tobacco (Nicotiana tabacum L. cv. 'Barley 21') cells were grown in a modified MS medium without glycine, and containing $3 \%(\mathrm{w} / \mathrm{v})$ sucrose. The cells in their logarithmic growth phase were treated with or without $80 \mu \mathrm{M}$ aluminum in the form of $\mathrm{AlCl}_{3}$, for $1 \mathrm{~h}$. Potentially useful tools in the analysis of MAPK pathways are commercially available, specific inhibitors of certain steps in the pathway. Therefore, a group of cells were also treated with $80 \mu \mathrm{M} \mathrm{Al}$ in the presence of $40 \mu \mathrm{M}$ PD98059, as a non-competitive inhibitor of activation of MAPKK. $\mathrm{Al}$ and PD98059 were added to the cell suspensions after 
78

filter sterilization. After the desired periods of treatment, the cells were harvested, washed thoroughly with medium, frozen in liquid $\mathrm{N}_{2}$ and kept at $-80^{\circ} \mathrm{C}$ for further analysis.

\section{Determination of the level of lipid peroxidation}

The level of damage of membranes was determined by measuring malonyldialdehyde (MDA) as the end product of peroxidation of membrane lipids. The traditional method for MDA determination has been the thiobarbituric acid (TBA) assay owing to its simplicity. In this method, MDA reacts with TBA via an acid-catalyzed nucleophilicaddition reaction, yielding a pinkish-red chromophore with a maximum absorbance at $532 \mathrm{~nm}$. However, TBA is not specific for MDA, and many other compounds e.g., simple carbohydrates and pigments which are present in many plant extracts, may interfere with the TBA assay. To avoid these interferences, improved methods have been developed (Du and Bramlage, 1992; Hodges et al., 1999). A $0.5 \mathrm{~g}$ aliquot of frozen powder was added to $5.0 \mathrm{ml} 0.1 \%$ $(\mathrm{w} / \mathrm{v})$ trichloroacetic acid and centrifuged at 10,000 $\times g$ for $5 \mathrm{~min}$. A $1 \mathrm{~mL}$ aliquot of supernatant was added to 1 $\mathrm{mL} 0.5 \%(\mathrm{w} / \mathrm{v})$ thiobarbituric acid in $20 \%(\mathrm{w} / \mathrm{v})$ trichloroacetic acid. The mixture was heated at $100^{\circ} \mathrm{C}$ for $30 \mathrm{~min}$ and then quickly cooled in an ice bath. After centrifugation at $10,000 \times g$ for $10 \mathrm{~min}$, the $\mathrm{A}_{532}, \mathrm{~A}_{600}$ and $\mathrm{A}_{440}$ values of the supernatant were recorded. The value for nonspecific absorption at $600 \mathrm{~nm}$ was subtracted and a standard curve of sucrose (from 2.5 to $10 \mathrm{mmol} \mathrm{mL}^{-1}$ ) was used to correct the results from the interference of soluble sugars in samples, reading $\mathrm{A}_{532}$ and $\mathrm{A}_{440}$. Malondealdehyde content was calculated using its absorption coefficient of 157 $\mathrm{mmol}^{-1} \mathrm{~cm}^{-1}$ and expressed as nmol g${ }^{-1} \mathrm{FW}$.

\section{Extraction and assay of the enzymes involved in ROS scavenging}

Frozen samples (200 mg fresh weight) were homogenized in $3 \mathrm{~mL}$ HEPES-KOH buffer $(\mathrm{pH} 7.8)$ containing $0.1 \mathrm{mM}$ EDTA. The homogenate was centrifuged at $12,000 \times g$ for $20 \mathrm{~min}$. All operations were performed at $4^{\circ} \mathrm{C}$. In the supernatant, SOD was assayed by a photochemical method (Cakmak and Horst, 1991). The reaction mixture $(3 \mathrm{~mL})$ consisted of $50 \mathrm{mM}$ HEPES-KOH buffer ( $\mathrm{pH} 7.8$ ), $0.1 \mathrm{mM}$ EDTA, $50 \mathrm{mM} \mathrm{Na} \mathrm{CO}_{3}(\mathrm{pH}$ 10.2), $12 \mathrm{mM} \mathrm{L}$ - methionine, $75 \mu \mathrm{M}$ NBT, $300 \mu \mathrm{L}$ enzyme extract and $1 \mu \mathrm{M}$ riboflavin. One unit SOD activity was defined as the amount of enzyme required to result in a $50 \%$ inhibition of NBT reduction measured at $560 \mathrm{~nm}$.

Activity of CAT was measured in a reaction mixture consisting of $25 \mathrm{mM} \mathrm{Na}$-phosphate buffer ( $\mathrm{pH}$ 6.8), 10 $\mathrm{mM} \mathrm{H}_{2} \mathrm{O}_{2}$ and adequate amount of enzyme extract. The decomposition of $\mathrm{H}_{2} \mathrm{O}_{2}$ was followed by the decline in absorbance at $240 \mathrm{~nm}$ (Cakmak and Horst, 1991; Ghanati et al., 2005). Protein contents were determined by the method of Bradford (1976), using BSA as standard.

\section{Radical scavenging capacity}

Evaluation of the total radical scavenging capacity of the cell extracts was conducted by using the stable 2.2'diphenylpicrylhydrazyl radicals (DPPH). In this method, the hydrogen atom level (or electron-donating ability) is measured from the bleaching of the purple-colored ethanol solution of DPPH. One-half $\mathrm{mL}$ of various ethanol extracts were diluted $1 / 10$ and were added to 2.5 $\mathrm{mL}$ of a $1 \mathrm{mM}$ ethanol solution of DPPH. After $40 \mathrm{~min}$ of incubation at room temperature, the absorbance was read against a blank at $517 \mathrm{~nm}$. The total capacity of scavenging of DPPH in percent was calculated as follows (Burits and Bucar, 2000; Stef et al., 2009):

Total radical scavenging capacity $(\%)=($ A blank $-\mathrm{A}$ sample)/A blank $\times 100$.

\section{$R N A$ extraction and RT-PCR analysis}

Total RNA was extracted according to the procedure previously described by Seyedi et al. (1999). Samples (ca. $2 \mathrm{~g}$ ) were ground to a fine powder in liquid nitrogen using a mortar and pestle. The powder was extracted in $4 \mathrm{~mL}$ of a buffer containing $50 \mathrm{mM}$ Tris- $\mathrm{HCl}, \mathrm{pH} 8.0,4.0 \%(\mathrm{w} / \mathrm{v})$ $\mathrm{p}$-aminosalicylate, $1.0 \%(\mathrm{w} / \mathrm{v})$ tri-isopropylnaphthalene sulfonate (sodium salt), and 2.0\% (v/v) mercaptoethanol. The aqueous phase was blended with an Ultra-Turrax in an equal volume of phenol [containing $0.1 \%(\mathrm{w} / \mathrm{v})$ hydroxyquinoline]: chloroform $(1: 1, \mathrm{v} / \mathrm{v})$. The homogenate was partitioned by centrifugation at $5,800 \times g$ for $20 \mathrm{~min}$. The total nucleic acids within the aqueous phase were precipitated by addition of 0.1 volume of $3 \mathrm{M}$ sodium acetate and 2.2 volumes of ethanol. After $4 \mathrm{~h}$ at $-20^{\circ} \mathrm{C}$, the nucleic acids were centrifuged at $20,000 \times \mathrm{g}$ for $30 \mathrm{~min}$. The pellet was re-suspended in $500 \mu \mathrm{L}$ of $\mathrm{H}_{2} \mathrm{O}$ and $\mathrm{LiCl}$ was added to a final concentration of $2.7 \mathrm{M}$. The RNA was selectively precipitated at $4^{\circ} \mathrm{C}$ overnight and centrifuged in a microfuge for $10 \mathrm{~min}$ to collect the pellet. The RNA was washed sequentially in $3 \mathrm{M}$ sodium acetate and 70\% ethanol before drying and re-suspending in water. The RNA absorbance was scanned between 320 and $220 \mathrm{~nm}$ and quantified at $260 \mathrm{~nm}$ before storage at $-70^{\circ} \mathrm{C}$.

Semi-quantitative RT-PCR was performed with Accupower RT premix (Bioneer, Daejon, Korea) following the manufacturer's protocol using gene-specific primers of Nicotiana tabacum SIPK (Seo et al., 2007) (forward: 5'-GGA AGG CTG AGG CAA TAA CA-3', reverse: 5'-GTA CAA AGG GCA GGG ACG TA-3') and 18S rRNA from Crocus sativus (forward, 5' - TCC ACC ACC ACA GAG AGA GG-3', reverse 5'-GAC AGT GCT CCT CAG ATA AA-3') as a housekeeping gene.

Quantification of RT-PCR analysis was performed using UV tech software (version 12.5.0.0). Sequence analysis of the PCR products conducted using BLAST confirmed $100 \%$ similarity between PCR products and expected sequence of tobacco SIPK. 
Statistical analysis

All of the experiments were carried out with at least three independent repetitions. All values are shown as the mean \pm SD. Statistical analysis was performed using Student's T-test and the differences between treatments were expressed as significant at level of $\mathrm{p} \leq 0.05$.

\section{Results and discussion}

In comparison with the control cells, $\mathrm{Al}$ treatment rapidly and significantly lowered the level of LPO of tobacco cells (Fig. 1).

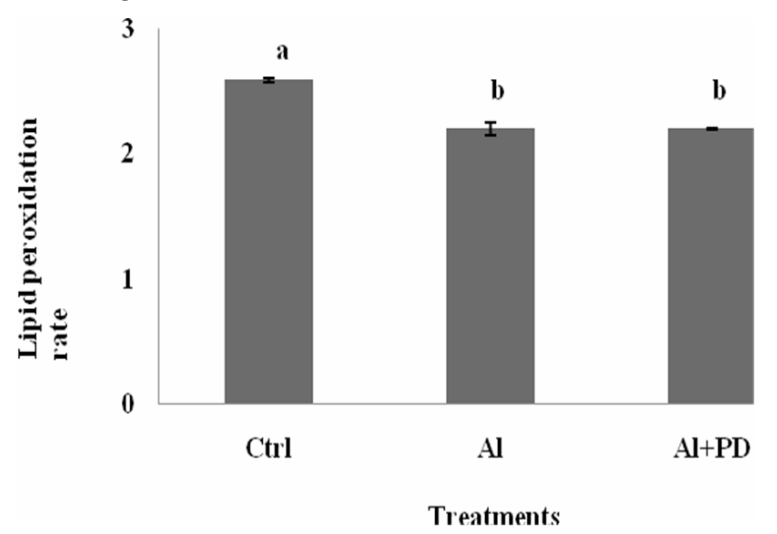

Fig. 1. Effect of $\mathrm{Al}$ on the rate of lipid peroxidation in suspension cultured-tobacco cells. Data are presented as the means \pm $\mathrm{SD}$ with $\mathrm{n}=3$. Bars with different letters are significantly different at $\mathrm{p} \leq 0.05$, according to the Student's T-test

Treatment with Al for $1 \mathrm{~h}$, also caused significant increase of SOD and CAT activity, which was accompanied by significant increase of total scavenging capacity of tobacco cells (Fig. 2).

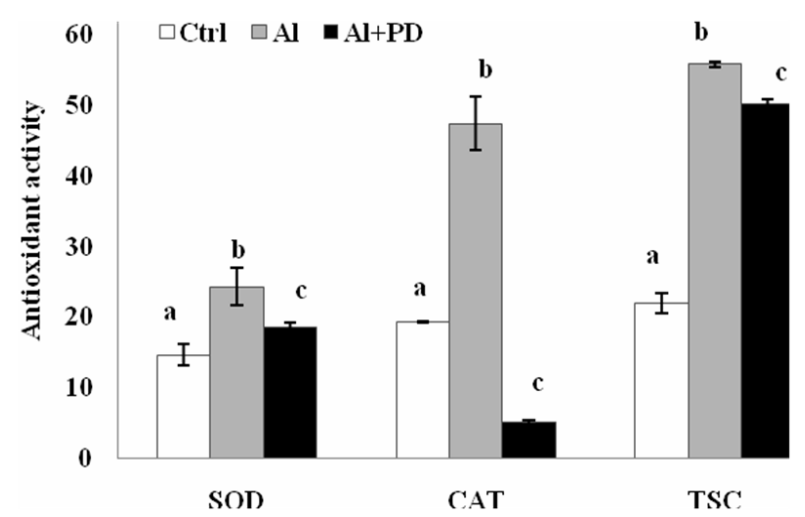

Fig. 2. Effect of $\mathrm{Al}$ on the antioxidant activity of tobacco cells. SOD was calculated as Unit/ $\mathrm{mg}$ protein, CAT as $\Delta \mathrm{A}_{240} / \mathrm{mg}$ protein, and TSC (total scavenging capacity) as \% of scavenging DPPH. Data are presented as the means $\pm S D$ with $n=3$. Bars with different letters are significantly different at $\mathrm{p} \leq 0.05$, according to the Student's T-test
Treatment of tobacco cells with $\mathrm{Al}$, also increased the expression of the SIPK gene, compared to the control cells (Fig. 3).

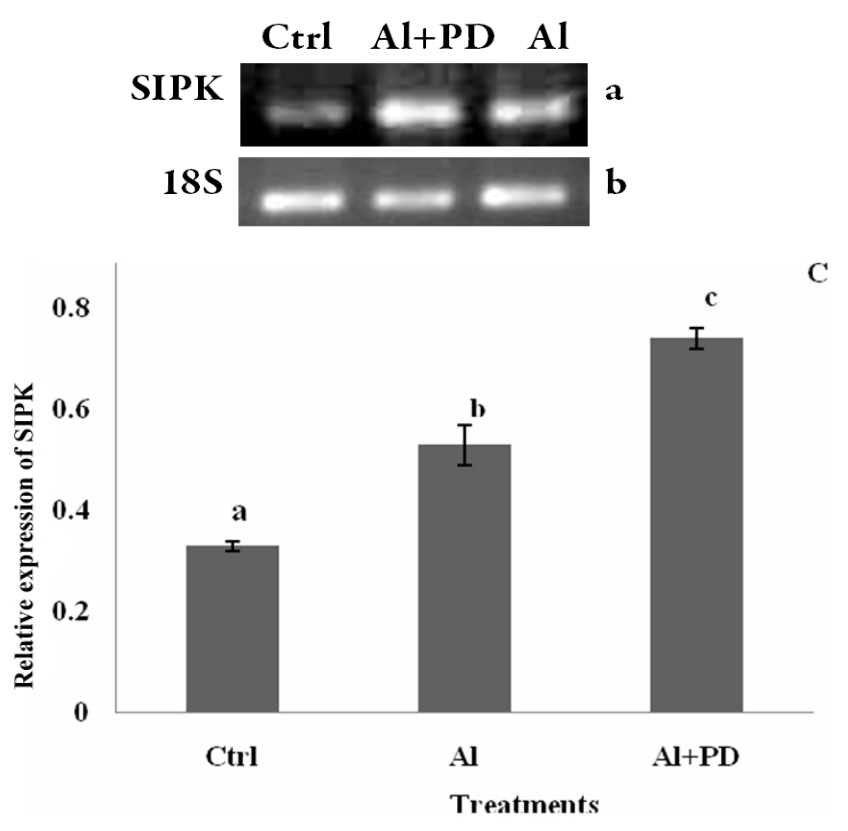

Fig. 3. RT-PCR analysis of the expression of the SIPK gene (a), in comparison with the $18 \mathrm{~S}$ rRNA gene (b), in suspension cultured-tobacco cells, and quantification of the expression level using UV tech software (c). Data are presented as the means \pm SD with $n=3$. Bars with different letters are significantly different at $\mathrm{p} \leq 0.05$, according to the Student's T-test

The rate of membrane lipid peroxidation of the cells lowered by $\mathrm{Al}$ together with the MAPKK inhibitor PD98059 (PD), compared to that of the control cells, but there was no significant difference between the level of $\mathrm{LPO}$ in $\mathrm{Al}$ and $\mathrm{Al}+\mathrm{PD}$ treatments (Fig. 1). Treatment of tobacco cells with $\mathrm{Al}+\mathrm{PD}$ significantly decreased radical scavenging capacity, and the activities of SOD and CAT, which were increased by the treatment with $\mathrm{Al}$ alone (Fig. 2).

The relative expression of the SIPK gene in $\mathrm{Al}+\mathrm{PD}$ treated tobacco cells was significantly higher than those of either control or Al-treated cells (Fig. 3).

Aluminum itself is not a transition metal and does not catalyze redox reactions; nonetheless, the involvement of oxidative stress in $\mathrm{Al}$ toxicity has been suggested (Ghanati et al., 2005; Yamamoto et al., 2003). Rapid and temporary induction of a $58 \mathrm{KDa}$ protein kinase in response to a toxic concentration of $\mathrm{Al}$ has been monitored immunologically in suspension cultured-coffee cells (Arroyo-Serralta et al., 2005). Despite the fact that ROS can induce MAPK activation, no direct genetic evidence has linked ROS-induced MAPK activation with antioxidant enzymes activation due to $\mathrm{Al}$ stress. It is striking that so many stresses that elicit ROS accumulation in plant cells, consis- 
80

tently appear to activate MAPK modules as one of their earliest effects. The MAPK signal transduction cascade is the route through which eukaryotic cells deliver extracellular messages to the cytosol and nucleus (Morris, 2001). A variety of stress responses have been found to involve the rapid activation of a specific subset of plant MAPKs, e.g. Arabidopsis MPK6, wound-induced protein kinase (WIPK) and SIPK in tobacco, and salt stress-induced MAPK (SIMK) in alfalfa (Cardinale et al., 2000; Yuasa et al., 2001; Zhang and Liu, 2001).

Reactive oxygen species production is closely related to the response of plants to heavy metals (Nagajyoti et al., 2010). It is also clear that heavy metals activate MAPKs in several plant systems (Pitzschke and Hirt, 2006). Depending on heavy metal identity, four alfalfa MAPKs become activated in a complex pattern (Jonak et al., 2004). In tobacco, the major ROS-induced MAPK is SIPK because one of the central functions of SIPK in the cell is to help monitor and regulate the cellular redox state. Activation of SIPK might play an important role in determining the response and ultimate fate of the stressed cells (Samuel and Ellis, 2002; Samuel et al., 2005).

Al-induced oxidative stress has been most commonly attributed to alterations in membrane structure, which then favor radical chain reactions mediated by Fe, resulting in the formation of lipid peroxides (Yamamoto et al., 2003). The rapid and significant increase of SOD activity in Al-treated tobacco cells was probably triggered to scavenge membrane-damaging superoxide radicals, which in turn resulted in the production of more hydrogen peroxide. Thus, the activation of CAT to detoxify excessively produced $\mathrm{H}_{2} \mathrm{O}_{2}$ is reasonable. Superoxide dismutase and CAT are supposed to be the key enzymes in detoxification of ROS; however, the involvement of other enzymes (e.g., glutathione reductase, ascorbate peroxidase), as well as nonenzymatic antioxidants (e.g. ascorbic acid, polyphenols, etc.) should not be overlooked. Although such components were not measured in othe present experiments, the significant increase of total scavenging capacity of Altreated tobacco cells implies that Al has triggered many nonenzymatic and enzymatic routes, resulting in lowering peroxidation of membrane lipids.

Increase of SIPK expression in Al-treated tobacco cells in comparison with the untreated (control) cells suggests that SIPK (and probably other members of MAPK cascade) are involved in transmitting the $\mathrm{Al}$ stress signal. Activation of SIPK both by harpin and direct oxidants was interrupted by pre-treatment with the MAPKK inhibitor, PD98059 (Samuel et al., 2005). Use of this inhibitor with $\mathrm{Al}$ was appropriate to show the relationship between $\mathrm{Al}$ induced SIPK expression and activation of antioxidant systems. The result presented here demonstrated that challenge with $\mathrm{Al}+\mathrm{PD} 98059$ rapidly enhanced the expression of SIPK. The exact mechanisms by which inhibition of kinase activity of MAPKK influenced the expression of the SIPK gene, remains to be clarified, but it is likely that to- bacco cells try to compensate the inhibition of the activity of an upstream protein in the MAPK cascade by increasing transcripts levels of a downstream module, SIPK.

Inhibition of the kinase activity of MAPKK in those cells treated with $\mathrm{Al}+\mathrm{PD} 98059$ suppressed the activity of both SOD and CAT, an effect more pronounced regarding catalase activity. Time course monitoring of expression of the CAT gene in the presence of MAPK inhibitors, with or without $\mathrm{Al}$, may help to clarify whether MAPK regulates ROS scavenging proteins at the transcriptional or postranscriptional level.

Most previous researches have shown adverse effects of $\mathrm{Al}$ on plant growth and enhancement of ROS. They attributed this to the existence of $\mathrm{Al}$ in acidic conditions as polyvalent cations which bind strongly to the negative charges in the cell (Poschenrieder et al., 2008; Rbia et al., 2011; Rengel and Reid, 1997; Zhang et al., 2010). Previous study showed, however, that most of the supplied Al was absorbed by tobacco cells in MS medium, $\mathrm{pH} 5.5$ (Shokuhi and Ghanati, 2007). It is generally assumed that under conditions with $\mathrm{pH}$ higher than 5.0, $\mathrm{Al}$ absorption would be limited, because $\mathrm{Al}$ forms insoluble species such as aluminum hydroxide. However, working on the effect of $\mathrm{Al}$ uptake on disease resistance of Nicotiana rustica, Zhang et al. (2010) showed that aluminum hydroxide also induced $\mathrm{H}_{2} \mathrm{O}_{2}$ accumulation through non-enzymatic and enzymatic regulation, ultimately resulting in resistance to tobacco wilt disease. Hydrogen peroxide is phytotoxic at higher concentrations but may function as a secondary messenger at low concentrations. Therefore, it may play two different roles in plant adaptation to both biotic and abiotic stresses: exacerbating damage or signaling the activation of defense responses (Dat et al., 2000).

\section{Conclusions}

The results presented here showed that $\mathrm{Al}$ rapidly promoted the activity of ROS scavenging systems in tobacco cells, probably by production of low amounts of hydrogen peroxide, and that this effect was somehow mediated by a MAPK route.

\section{References}

Arroyo-Serralta GA, Kú-González Á, Hernández-Sotomayor SMT, Aguilar JJZ (2005). Exposure to toxic concentrations of aluminum activates a MAPK-like protein in cell suspension cultures of Coffea arabica. Plant Physiol Biochem 43:27-35.

Bradford MM (1976). A rapid and sensitive method for the quantitation of microgram quantities of protein utilizing the principle of protein-dye binding. Anal Biochem 72:284254.

Burits M, Bucar F (2000). Antioxidant activity of Nigella sativa essential oil. Photother Res 14:323-328.

Cakmak I, Horst WJ (1991). Effect of aluminum on lipid 
peroxidation, superoxide dismutase, catalase, and peroxidase activities in root tips of soybean (Glycine max). Physiol Plant 83:463-468.

Cardinale F, Jonak C, Ligterink W, Niehaus K, Boller T, Hirt $\mathrm{H}$ (2000). Differential activation of four specific MAPK pathways by distinct elicitors. J Biol Chem 275:3673436740.

Dat J, Vandenabeele S, Vranová E, Van Montagu M, Inzé D, Van Breusegem F (2000). Dual action of the active oxygen species during plant stress responses. Cell Mol Life Sci. 57:779-795.

Du Z, Bramlage WJ (1992). Modifed thiobarbituric acid assay for measuring lipid oxidation in sugar-rich plant tissue extracts. J Agr Food Chem 40:1566-1570.

Ghanati F, Morita A, Yokota H (2005). Effect of aluminium on the growth of tea plant and activation of antioxidant system. Plant Soil 276:133-141.

Hodges DM, Delong JM, Forney CF, Prange RK (1999). Improving the thiobarbituric acid-reactive-substances assay for estimating lipid peroxidation in plant tissues containing anthocyanin and other interfering compounds. Planta 207:604-611.

Jonak C, Nakagami H, Hirt H (2004). Heavy Metal Stress. Activation of distinct mitogen-activated protein kinase pathways by copper and cadmium. Plant Physiol 136:32763283.

Jones DL, Shaff JE, Kochian LV (1995). Effect of aluminum on calcium homeostasis and $\mathrm{IP}_{3}$ mediated signal-transduction in Triticum aestivum and Nicotiana plumbaginifolia. Plant Physiol 108:41-43.

Morris PC (2001). MAP kinase signal transduction pathways in plants. New Phytol 151:67-89.

Nagajyoti PC, Lee KD, Sreekanth TVM (2010). Heavy metals, occurrence and toxicity for plants: a review. Environ Chem Lett 8:199-216.

Pitzschke A, Hirt H (2006). Mitogen-Activated protein kinases and reactive oxygen species signaling in plants. Plant Physiol 141:351-356,

Poschenrieder Ch, Gunsé B, Corrales I, Barceló J (2008). A glance into aluminum toxicity and resistance in plants. Sci Total Environ 400:356-368.

Rbia O, Horchani F, Smida I, Mejri M, Aschi-Smiti S (2011). Aluminium phytotoxicity and plant acclimation to acidic soils. Int J Agr Res 6:194-208.
Rengel Z, Reid RJ (1997). Uptake of Al across the plasma membrane of plant cells. Plant Soil 192:31-35.

Samuel MA, Ellis BE (2002). Both overexpression and suppression of a redox-activated plant mitogen-activated protein kinase render tobacco plants ozone sensitive. Plant Cell 14:2059-2069.

Samuel MA, Hall H, Krzymowska M, Drzewiecha K, Henning J, Ellis BE (2005). SIPK signaling controls multiple components of harpin-induced cell death in tobacco. The Plant J 42:406-416.

Schmohl N, Horst WJ (2000). Cell wall pectin content modulates aluminum sensitivity of Zea mays L. cells grown in suspension culture. Plant Cell Environ 23:735-742.

Seo Sh, Katou Sh, Seto H, Gomi K, Ohashi Y (2007). The mitogen-activated protein kinases WIPK and SIPK regulate the levels of jasmonic and salicylic acids in wounded tobacco plants. Plant J 49:899-909.

Seyedi M, Timko MP, Sundqvist C (1999). NADPHprotochlorophyllide oxidoreductase, and chlorophyll formation in the lip1 mutant of pea. Physiol Plant 106:344354.

Shokuhi Kh, Ghanati F (2007). Aluminum-induced growth inhibition and changes in cell wall components of tobacco cells. J Sci Teacher Train Univ 7:855-864.

Stef DS, Gergen I, Traska TI, Harmanescu M, Lavinia S, Ramona B, Heghedus MG (2009). Total antioxidant and radical scavenging capacities for different medicinal herbs. Rom Biotechnol Lett 14:4704-4709.

Yamamoto Y, Kobayashi Y, Devi SR, Rikiishi S, Matsumoto $\mathrm{H}$ (2003). Oxidative stress triggered by aluminum in plant roots. Plant Soil 255:239-243.

Yuasa T, Ichimura K, Mizoguchi T, Shinozaki K (2001). Oxidative stress activates ATMPK6, an Arabidopsis homologue of MAP kinase. Plant Cell Physiol 42:10121016.

Zhang S, Liu Y (2001). Activation of salicylic acid-induced protein kinase, a mitogen-activated protein kinase, induces multiple defense responses in tobacco. Plant Cell 13:18771889.

Zhang B, Wang X, Li X, Ni Y, Li H (2010). Aluminum uptake and disease resistance in Nicotiana rustica leaves. Ecotoxicol Environ Safety 73:655-663. 